\title{
Identification of Soybean Genotypes Resistant to Cercospora sojina by Field Screening and Molecular Markers
}

\author{
Rouf Mian, United States Department of Agriculture-Agricultural Research Service (USDA-ARS), The Ohio State \\ University, Wooster 44691; Jason Bond, Southern Illinois University, Carbondale 62901; Tarek Joobeur, Molecular \\ and Cellular Imaging Center, The Ohio State University, Wooster; Alemu Mengistu, USDA-ARS, Jackson, TN \\ 38301; William Wiebold, University of Missouri, Columbia 65211; and Grover Shannon and Allen Wrather, Uni- \\ versity of Missouri, Portageville 63873
}

\begin{abstract}
Mian, R., Bond, J., Joobeur, T., Mengistu, A., Wiebold, W., Shannon, G., and Wrather, A. 2009. Identification of soybean genotypes resistant to Cercospora sojina by field screening and molecular markers. Plant Dis. 93:408-411.

Frogeye leaf spot (FLS) of soybean, caused by Cercospora sojina, has been a problem in the southern United States for many years and has recently become a greater problem in the northern United States. Cultivars resistant to FLS have been developed for planting in the southern United States and resistance in many of these cultivars is conditioned by the Rcs 3 gene. This gene conditions immunity to all known races and isolates of the pathogen. Resistance to C. sojina in soybean genotypes (cultivars and breeding lines) adapted to north-central U.S. production region is unknown. The objectives of this study were to (i) identify maturity group (MG) III, IV, and $\mathrm{V}$ soybean genotypes resistant to $C$. sojina race 11 by field screening at multiple locations over years and (ii) determine whether FLS resistance in these genotypes is likely to be conditioned by the $R \operatorname{cs} 3$ gene. In total, 1,350 genotypes were evaluated for resistance to race 11 in field trials, and 13 MG III, 45 MG IV, and 15 MG V genotypes did not develop symptoms of FLS. Of these, 54 were subsequently tested for the possible presence of Rcs 3 using five molecular markers located within 2 centimorgans $(\mathrm{cM})$ of the gene. None of the MG III genotypes tested had the Rcs3 haplotype of cv. Davis, the source of Rcs3; six of the MG IV genotypes and seven of the MG V genotypes had the Rcs 3 haplotype. This is the first report of the presence of the Rcs3 haplotype in LN 97-15076 and S99-2281. The soybean genotypes predicted to have the $R c s 3$ gene and other genotypes with no FLS symptoms in field trials may be useful in developing soybean cultivars with broad resistance to FLS and adapted to the northern United States.
\end{abstract}

Frogeye leaf spot (FLS) of soybean, caused by Cercospora sojina Hara, is a common disease of soybean in many countries of the world (7). It was first reported on soybean in Japan in 1915 and in the United States in 1924 (11). Symptoms of FLS develop primarily on foliage of soybean even though seed, pods, and stems can also become infected (21). The seedlings from infected seed may have lesions on the cotyledons (25). Spores produced on infected cotyledons and infected residue from pervious soybean crops have been reported to become inoculum that may infect young leaves, but this seems to be based on empirical evidence. The contribution of spores from cotyledon lesions compared with crop residue for infection of young leaves is not known. The lesions do not appear on leaves for nearly 7 to 14 days after invasion of the host tissue; therefore, they are

Corresponding author: A. Wrather

E-mail: wratherj@missouri.edu

Accepted for publication 18 December 2008.

doi:10.1094/PDIS-93-4-0408

(C) 2009 The American Phytopathological Society not observed on young expanding leaves (21).

The impact of FLS on soybean yield is mainly due to reduction in photosynthetic leaf area by necrotic lesions or premature defoliation (1). Yield reductions of 10 to $60 \%$ due to FLS have been reported (13). FLS can cause significant yield suppression in the warm and humid environments of the southern United States, and it recently has suppressed yields in Iowa (29) and Wisconsin (12). The reason for changes in incidence and severity of FLS in some northern states is not clear but may be due to recent changes in the environment and increased usage of no-till cultivation (28).

FLS may be partially managed by planting disease-free seed, treatment of seed with a fungicide before planting, crop rotation, treatment of R2 to R5 growth stage soybean foliage with fungicides, and planting resistant cultivars if available. Three single genes conditioning resistance to $C$. sojina are currently recognized by the Soybean Genetics Committee. Rcs 1 in 'Lincoln' was the first gene identified, and it conditioned resistance to race 1 of $C$. sojina (2). Rcs 2 in 'Kent' conditioned resistance to race 2 (3), and Rcs3 in 'Davis' conditioned resistance to race 5 and to all other known races of $C$. sojina in the United States (22) as well as to all isolates from Brazil (30). Other dominant genes for resistance to race 5 were found in 'Ransom', 'Stonewall', and 'Lee' in 1993, and each of these genes was nonallelic to Rcs 3 and to each other (20). Another single dominant gene reported as nonallelic to Rcs 3 from cv. Peking was found later that provided resistance against many isolates of C. sojina (4).

A simple sequence repeat (SSR) marker, Satt244, on linkage group J of the soybean genetic map was reported to be within 1 centimorgan (cM) of the Rcs3 gene (16). This SSR marker has been successfully used for marker-assisted selection (MAS) of this gene (18). Recently, several singlenucleotide polymorphism (SNP) and insertion deletion (INDEL) markers that are located within $3 \mathrm{cM}$ of the $R \operatorname{cs} 3$ gene have been developed, confirmed, and applied for MAS for $R \operatorname{cs} 3$ (17). MAS with SNP markers is most effective if several SNPs that are evenly spaced and closely linked to the gene of interest are used to define a haplotype of the genomic region flanking the gene (8). Molecular markers for Rcs 1 and $R c s 2$ have not been developed.

Some maturity group MG V to VIII FLS-resistant cultivars were developed for planting in the southern United States, and resistance in a few is conditioned by $R c s 3$. Resistance to $C$. sojina in soybean genotypes adapted to the north-central U.S. production region is unknown. The objectives of this project were to (i) identify MG III, IV, and V soybean genotypes (cultivars and lines) resistant to $C$. sojina race 11 by field screening at multiple locations over years and (ii) determine whether FLS resistance in these genotypes is likely to be conditioned by the $R \operatorname{cs} 3$ gene.

\section{MATERIALS AND METHODS}

Field screening. Field plots were established in 2003-05 at the University of Missouri-Delta Center near Portageville and Southern Illinois University near Carbondale. Approximately 400 to 600 soybean genotypes in MG III, IV, and V were tested in 2003-05 for their reaction to $C$. sojina race 11 (15). Screening in the field or greenhouse has been the only method available until recently for evaluating genotypes for reaction to $C$. sojina. There 
are many disadvantages to field screening, such as the impact of weather on the results; the time required; and the difficulties of inoculating with one race, multiple races, or relying on natural inoculum. We screened genotypes in the field because of limited greenhouse space. Prior to planting each year, the field was disked twice and $75-$ to $96-\mathrm{cm}$ row beds were formed. The top $10 \mathrm{~cm}$ of the beds was pushed off just prior to planting to form a flat-top ridge. The herbicides imazaquin $\left(0.02 \mathrm{~kg}\right.$ a.i. $\left.\mathrm{ha}^{-1}\right)$ and alaclor $\left(0.4 \mathrm{~kg}\right.$ a.i. $\left.\mathrm{ha}^{-1}\right)$ were preplant incorporated into the flat-top ridges. Planting dates were 15 to 20 May each year in Missouri and 20 May to 1 June each year in Illinois. The soybean genotypes tested each year were those entered in the University of Missouri soybean MG III, IV, and $\mathrm{V}$ cultivar performance trials; the United States Department of Agriculture soybean cyst nematode MG IV uniform test; and the uniform MG IV test north and south. Seed of genotypes that were resistant to this pathogen in field trials were collected and tested the next year, and approximately 1,350 different genotypes were tested at multiple locations and years. Ten seeds of each genotype were planted in hills in the center of the ridge with a hand-held "jab" planter, and hills were spaced $0.6 \mathrm{~m}$ apart. The test site was treated with a post-emergence directed application of bentazon $\left(0.56 \mathrm{~kg}\right.$ a.i. $\left.\mathrm{ha}^{-1}\right)$ and clethodim $\left(0.14 \mathrm{~kg}\right.$ a.i. $\left.\mathrm{ha}^{-1}\right)$ at the V6 stage of soybean growth (6). Plots were cultivated once and hand weeded each year as necessary. Plots were irrigated by overhead sprinkler. The tests were rotated with corn to minimize the presence of natural inoculum. Genotypes were planted in a randomized complete block design with two replications at each test site each year.

Evaluation of genotype reaction to $\boldsymbol{C}$. sojina. Genotypes in all studies at all locations were inoculated with the same isolate of $C$. sojina race 11 (15). It was used because it was virulent, and inoculation with multiple races may have masked resistance to this race. Resistance to this race is conditioned by $R c s 2, R c s 3$, and the single dominant gene in Peking (15). This isolate was cultured on Emerson medium (27) at $25^{\circ} \mathrm{C}$ on a laboratory bench for 7 days. The culture was then flooded with sterile deionized water and the culture surface was rubbed manually to dislodge conidia. The conidia suspension was filtered through cheese cloth, the concentration was adjusted to $1 \times 10^{-5}$ conidia $/ \mathrm{ml}$, and Tween 20 was mixed with the suspension $(0.003$ $\mathrm{vol} / \mathrm{vol}$ ). Before inoculation, 30-day-old plants were sprinkle irrigated for $30 \mathrm{~min}$ at 8:00 p.m., and the plants in each hill were then sprayed with approximately $30 \mathrm{ml}$ of inoculum. Genotype reaction to $C$. sojina was evaluated 14 days after inoculation using a 0-to-9 scale developed by the Southern Soybean Disease Workers, where $0=$ no disease and $9=90 \%$ leaf tissue diseased (26). All genotypes without symptoms 14 days after inoculation were further evaluated for reaction to $C$. sojina at 21 and 28 days after inoculation. Genotypes without symptoms in all replications, trials, and years were considered resistant to $C$. sojina race 11 .

Field screening analysis. Genotype reactions to FLS were subjected to an appropriate analysis of variance. Fisher's least significant difference test was used for mean comparison $(P=0.05)(10)$. Only

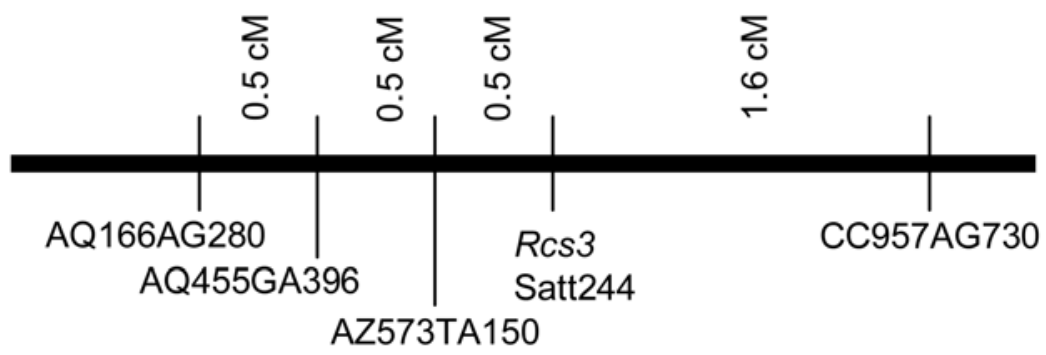

Fig. 1. Position of the three single-nucleotide polymorphism markers (AQ166AG280, AQ455GA396, and CC957AG730), one insertion deletion (AZ573TA150), and one simple sequence repeat (Satt244) used to analyze the soybean genotypes. Marker position on linkage group $\mathrm{J}$, in relation to the position of the Rcs3 gene (adapted from Missaoui et al. [17]). those genotypes without symptoms at all locations and years were tested for the presence of $R \operatorname{cs} 3$. Our broader objective was to determine the reaction to $C$. sojina race 11 among genotypes, and the data on genotypes with significantly $>0$ symptom scores will be published later.

Prediction for the presence of the $\operatorname{Res} 3$ gene using molecular markers. Genotypes resistant to $C$. sojina race 11 in the field were tested for likelihood of carrying the Rcs 3 gene. Seedlings were grown from arbitrarily selected seed from a bag of seed of each genotype. For each genotype, young expanding leaf tissue from 10 arbitrarily selected seedlings was collected and bulked in a bag, immediately frozen in liquid nitrogen, and lyophilized in a freeze drier. The dry tissue was ground to a fine powder and DNA was extracted using a cetyltrimethylammonium bromide extraction method (23). Three SNPs (CC957AG730, AQ455GA396, and AQ166AG280), one INDEL (AZ573CA150), and one SSR (Satt244) marker that flank the Rcs3 gene and are located within $2 \mathrm{cM}$ of the gene (17) (Fig. 1) were used to screen 54 soybean genotypes which were resistant in the field to FLS. Two genotypes known to contain the $R \operatorname{cs} 3$ (Davis and 'Wright$R c s 3$ ') and 3 non- $R \operatorname{cs} 3$ genotypes (Lee, 'Blackhawk', and 'Wright') were included in the analysis as checks. The SNP detection was conducted using the allelespecific primer extension (ASPE) assay (9) with primer sequences listed in Table 1. The polymerase chain reaction (PCR) product for the markers AZ573CA150 (INDEL) and Satt244 were labeled using the M13-tailed primer PCR method $(14,19)$. The M13 oligonucleotide was labeled with one of the three WellRED fluorescent dyes (Beckman Coulter, Fullerton, CA) D2, D3, and D4. Fragment analysis and allele calling was done using the CEQ 8800 genetic analysis system software (Beckman Coulter).

\section{RESULTS}

Field screening. The reaction to $C$. sojina race 11 ranged from 0 to 8 and varied significantly among genotypes (data not shown). Of the 1,350 different soybean genotypes evaluated for reaction to race 11 in field trials, $13 \mathrm{MG}$ III, $45 \mathrm{MG} \mathrm{IV,} \mathrm{and}$ 15 MG V genotypes did not develop symptoms of FLS in at least four site

Table 1. Polymerase chain reaction (PCR) and allele-specific extension primer (ASPE) used for single-nucleotide polymorphism detection assay and PCR primers for insertion deletion AZ573TA150 (adapted from Missaoui et al. [17])

\begin{tabular}{llll}
\hline Marker & \multicolumn{1}{c}{ PCR primers } & \multicolumn{1}{c}{ Tag added to the ASPE primers } & \multicolumn{1}{c}{ ASPE primers } \\
\hline CC957AG730 & CCCCATTTGATATCCCACATT & TCAATTACTTCACTTTAATCCTTT & TTTAGTGCACTATTAATGACCA \\
& TGAGTTCGTTAGAAATCCTGCAT & TCATTCATATACATACCAATTCAT & TTTAGTGCACTATTAATGACCG \\
AQ166AG280 & AACCAAAGACACCCTAATCCAA & CAATTCATCATTCATTCATTTCA & GTAGGGACGAATAACCATGGTG \\
& GAGACCCAGGACCGAGTTG & CAATTCATTTCATTCACAATCAAT & GTAGGGACGAATAACCATGGTA \\
AQ455GA396 & AAACCTTGAAAGGCACAATTT & CTTTTCATCTTTTCATCTTTCAAT & GATTTCTTTTTAATTCGAATCATAAAG \\
& TGCGTGAACTCATCAGCAAC & TCAATCATTACACTTTTCAACAAT & GATTTCTTTTTAATTCGAATCATAAAA \\
AZ573TA150 & AAACTCCAACGCCAGATCAC & $\ldots$ & $\ldots$ \\
& GCCATTTAACGTGGGAAAAG & $\ldots$ & $\ldots$ \\
\hline
\end{tabular}


Table 2. Soybean genotypes resistant to Cercospora sojina race 11 in field studies at multiple locations during 2003 to 2005 and evaluated for the presence of the cv. Davis-like marker haplotype for Rcs 3 gene

\begin{tabular}{|c|c|c|c|c|c|}
\hline Genotype & $\begin{array}{c}\text { Maturity } \\
\text { group }\end{array}$ & $\begin{array}{c}\text { Davis } \\
\text { haplotype }^{\mathrm{z}}\end{array}$ & Genotype & $\begin{array}{c}\text { Maturity } \\
\text { group }\end{array}$ & $\begin{array}{c}\text { Davis } \\
\text { haplotype }^{x}\end{array}$ \\
\hline Delta Pine 3861 & III & No & Terral TVX 48 RL 27 & IV & No \\
\hline Dyna-Gro 33A37 & III & No & USG 7443 & IV & No \\
\hline Garst 3624 & III & No & Vigro V42N3RR & IV & No \\
\hline Golden Harvest 3606 & III & No & DT98-7278 & IV & No \\
\hline Kruger 355 & III & No & DT 98-9102 & IV & NT \\
\hline Kruger 379 & III & No & HC 97-1691 & IV & NT \\
\hline Lewis 3566 & III & No & HC 99-1261 & IV & NT \\
\hline Midland 9A373 & III & No & HC 99-2763 & IV & No \\
\hline Morsoy 3712 & III & No & HC 01-289 & IV & NT \\
\hline NuTech 3737 & III & No & LN 97-15076 & IV & Yes \\
\hline Renze 3684 & III & No & Md 97-6491 & IV & NT \\
\hline Stine $3532-4$ & III & No & Md 01-063 & IV & NT \\
\hline Taylor 374 & III & No & NT 4414 & IV & NT \\
\hline Asgrow 4801 & IV & No & R 99-2772 & IV & NT \\
\hline Bio Gene 4200 & IV & No & R 01-1017 & IV & NT \\
\hline Delta Grow 4340 & IV & No & S99-2281 & IV & Yes \\
\hline Delta King XT J543 & IV & No & S00-9925-10 & IV & NT \\
\hline Excel 8448 & IV & No & SS01-13352 & IV & No \\
\hline Garst 4212 & IV & No & SS01-17773 & IV & No \\
\hline Gateway 4RS421 & IV & No & SS02-8589 & IV & No \\
\hline Gateway 4R485 & IV & Yes & TN01-032 & IV & NT \\
\hline Kruger 440 RR/SCN & IV & NT & TN02-05 & IV & NT \\
\hline Kruger 442 & IV & No & Delta King XTJ554 & V & Yes \\
\hline Lewis 3715 & IV & No & Delta Pine 5414 & $\mathrm{~V}$ & Yes \\
\hline Mersch Austin & IV & No & Delta Pine 5808 & $\mathrm{~V}$ & NT \\
\hline Mersch Phoenix III & IV & No & Delta Pine 5915 & $\mathrm{~V}$ & Yes \\
\hline Midland 9A 373 & IV & No & Dyna-Gro 33B52 & $\mathrm{V}$ & NT \\
\hline Midland 9B 445 & IV & No & FFR 5225 & $\mathrm{~V}$ & NT \\
\hline Morsoy RT 4402 & IV & No & FFR 5663 & V & Yes \\
\hline Nutech NT 3737 & IV & No & Garst 5212 & V & No \\
\hline Pioneer 94B73 & IV & Yes & Hornbeck R5624 & $\mathrm{V}$ & Yes \\
\hline Pioneer 94M41 & IV & Yes & Progeny 5715 & $\mathrm{~V}$ & Yes \\
\hline Progeny 4304 & IV & No & Progeny 5770 & V & Yes \\
\hline Progeny 4949 & IV & Yes & USG 7523 & $\mathrm{~V}$ & No \\
\hline Southern Cross & IV & No & R00-1551 & V & NT \\
\hline Michael & & & R00-1940 & $\mathrm{V}$ & NT \\
\hline Stine $4102-4$ & IV & No & V00-1988 & $\mathrm{V}$ & NT \\
\hline
\end{tabular}

${ }^{\mathrm{z}} \mathrm{No}=$ the marker haplotype of the genotype did not match the marker haplotype of Davis for Rcs3, Yes $=$ the marker haplotype of the genotype was the same as the marker haplotype of Davis for Rcs3, and NT $=$ not tested. years (Table 2). Of these 73 genotypes without symptoms of FLS, 54 were tested for $\operatorname{Res} 3$.

MAS. Of the 54 soybean genotypes subjected to marker analysis for testing the likelihood of the presence of the Rcs 3 gene, only 12 lines had the Rcs 3 haplotype of cv. Davis (Table 3). Another genotype (S99-2281) also matched the haplotype of Davis except that there appears to be a crossover with a non-Rcs3 (Blackhawk) type background between Satt244 and SNP CC957AG730. The remaining genotypes did not fit the haplotype of Davis (data not shown). Wright-Rcs3, a near-isogenic line that was developed by incorporating the Rcs3 gene from Davis into Wright, also had the haplotype of Davis as expected. The three non-Rcs3 (FLS-susceptible) check cultivars all had the haplotype of the universally susceptible cv. Blackhawk.

\section{DISCUSSION}

The haplotypes of soybean genotypes established with the five molecular markers that are tightly linked to the $R \operatorname{cs} 3$ gene should be a reliable predictor regarding which of these genotypes may carry the gene. The exact match of the haplotype of the 12 genotypes with that of Davis indicates a high probability that these genotypes may carry the Rcs 3 gene. Three markers (AZ573CA150, AQ455GA396, and AQ166AG280) were close to the gene and located in a region of high linkage disequilibrium (17). These three markers can be confidently used as a haplotype tag for the Rcs3 gene (17). The same study (17) reported that this three-marker haplotype of all cultivars known to carry the $R \operatorname{cs} 3$ gene matched with the corresponding haplotype of Davis. In the current study, we have used these three markers in con-

Table 3. Soybean genotypes with cv. Davis-like marker haplotype for $R \operatorname{cs} 3$ gene ${ }^{\mathrm{x}, \mathrm{y}}$

\begin{tabular}{|c|c|c|c|c|c|}
\hline \multirow[b]{2}{*}{ Genotype } & \multicolumn{5}{|c|}{ Marker } \\
\hline & AQ166AG280 & AQ455GA396 & AZ573TA150 & Satt-244 & CC957AG730 \\
\hline Davis $^{z}$ & GG & GG & DD & DD & AA \\
\hline Wright-Rcs $3^{\mathrm{z}}$ & GG & GG & DD & DD & AA \\
\hline Progeny 5715 RR & GG & GG & DD & DD & AA \\
\hline Progeny 5770 & GG & GG & DD & DD & AA \\
\hline Dpl 5915 & GG & GG & DD & DD & AA \\
\hline Gateway 4R485 & GG & GG & DD & DD & AA \\
\hline Pioneer 94B73 & GG & GG & DD & DD & AA \\
\hline Pioneer 94M41 & GG & GG & DD & DD & AA \\
\hline LN97-15076 & GG & GG & DD & DD & AA \\
\hline Delta Pine 5414RR & GG & GG & DD & DD & AA \\
\hline FFR 5663 & GG & GG & DD & DD & AA \\
\hline Hornbeck R5624 & GG & GG & DD & DD & AA \\
\hline Delta King XT J554 & GG & GG & DD & DD & AA \\
\hline Progeny 4949 RR & GG & GG & DD & DD & AA \\
\hline S99-2281 & GG & GG & DD & DD & $G G$ \\
\hline $\operatorname{Lee}^{\mathrm{x}}$ & $A A$ & $A A$ & $B B$ & $B B$ & $G G$ \\
\hline Blackhawk $^{x}$ & $A A$ & $A A$ & $B B$ & $B B$ & $G G$ \\
\hline Wright $^{x}$ & $A A$ & $A A$ & $B B$ & $B B$ & $G G$ \\
\hline
\end{tabular}

${ }^{x}$ Genotypes known to carry homozygous susceptible allele $r c s 3$.

${ }^{y} \mathrm{GG}$ indicates the genotype is homozygous for nucleotide $\mathrm{G}$ at the single-nucleotide polymorphism (SNP), $\mathrm{DD}=$ homozygous for Davis allele, $\mathrm{AA}$ indicates that the genotype is homozygous for nucleotide $\mathrm{A}$ at the SNP, and BB = homozygous for Blackhawk allele.

${ }^{\text {z }}$ Genotypes known to carry homozygous resistance allele $R$ cs 3 . 
junction with two additional markersSatt244 and SNP CC957AG730- that are also closely linked to the gene. Thus, we predict that the 12 genotypes showing the exact marker haplotype of Davis for Rcs 3 in this study may carry the $R \operatorname{cs} 3$ gene for FLS resistance. Additionally, S99-2281 also has a high probability of carrying the Rcs 3 gene, because its haplotype for the three markers as well as Satt244 match with the Davis haplotype. A recombination event between Satt244 and CC957AG730 (located at $1.6 \mathrm{cM}$ from $R \operatorname{cs} 3$ ) could explain the observed haplotypes for S99-2281.

This is the first report on the Davis Rcs3 haplotype in public soybean lines S992281 (24) and LN97-15076 (5) along with 11 other private genotypes. These lines may be useful in soybean breeding programs for developing FLS-resistant soybean cultivars adapted to the northern United States. Though this molecularmarker-based prediction of the presence of $R \operatorname{cs} 3$ in these soybean lines should be robust, we suggest that one should verify the presence of $R \operatorname{cs} 3$ in these lines via phenotypic screening using the appropriate $C$. sojina races (15) before using them as donors of $R c s 3$ in a breeding program.

Because of intellectual property issues involved with private soybean cultivars, the 11 private cultivars are likely to be restricted in their use by breeding programs without permission of the originator of these genotypes. S99-2281, an early group V, University of Missouri line, has been released as a soybean germplasm line for use in soybean breeding programs to develop cultivars (24). Cv. LN 97-15076, mid-group IV, was released by the University of Illinois and is also available for unrestricted use in soybean improvement programs.

Genotypes that were resistant in these field screenings without the Rcs 3 haplotype may also be useful in breeding programs because they may carry novel resistance genes to $C$. sojina or Rcs 1 or the resistance gene in Lee. Those with partial resistance (data not shown) may also be useful, but their reaction to other $C$. sojina races must be evaluated.

\section{ACKNOWLEDGMENTS}

These studies were supported in part by the University of Missouri Agriculture Experiment Station, the Ohio State University Agriculture Experiment Station, and Southern Illinois University. We thank the North Central Soybean Research Program for the financial support from farmer soybean checkoff dollars through funding of the project titled "Managing Frogeye Leaf Spot and Charcoal Rot in the North Central Region"; J. Elrod for her efforts in this project; the employees of Molecular and Cellular Imaging Center (MCIC) for the SNP analysis; R. Boerma for providing valuable information and guidance for MAS; S. Beil for his technical help; and God for guidance.

\section{LITERATURE CITED}

1. Akem, C. N., and Dashiell, K. E. 1994. Effect of planting date on severity of frogeye leaf spot and grain yield of soybeans. Crop Prot. 13:607-610.

2. Athow, K. L., and Probst, A.H. 1952. The inheritance of resistance to frogeye leaf spot of soybeans. Phytopathology 42:660-662.

3. Athow, K. L., Probst, A. H., Kartzman, C. P., and Laviolette, F. A. 1962. A newly identified physiological race of Cercospora sojina on soybean. Phytopathology 52:712-714.

4. Baker, W. A., Weaver, D. B., Qiu, J., and Pace, P. F. 1999. Genetic analysis of frogeye leaf spot resistance in PI54610 and Peking soybean. Crop Sci. 39:1021-1025.

5. Diers, B. W., Cary, T. R., Thomas, D. J., and Nickel, C. D. 2004. Registration of 'LN9715076' Soybean. Crop Sci. 44:1483.

6. Fehr, W. R., Caviness, C. E., Burmood, D.T., and Pennington, J. S. 1971. Stage of development descriptions for soybeans, Glycine max (L.) Morrill. Crop Sci. 11:929-931.

7. Grau, C. R., Dorrance, A. E., Bond, J., and Russin, J. S. 2004. Fungal diseases. Pages 679763 in: Soybeans: Improvement, Production, and Uses, 3rd ed. H. R. Boerma and J. E. Specht, eds. Agron. Monogr. 16, ASA, CSSA, and SSSA, Madison, WI

8. Johnson, G. C. L., Esposito, L., Barratt, B. J., Smith, A. N., Heward, J, Di Genova, G., Ueda, H., Cordell, H. J., Eaves, I. A., Dudbridge, F., Twells, R. C., J., Payne, F., Hughes, W., Nutland, S., Stevens, H., Carr, P., TuomilehtoWolf, E., Tuomilehto, J, Gough, S. C. L., Clayton, D. G., and Todd, J. A. 2001. Haplotype tagging for the identification of common disease genes. Nat. Genet. 29:233-237.

9. Lee, S. H., Walker, D. R., Cregan, P. B., and Boerma, H. R. 2004. Comparison of four flow cytometric SNP detection assays and their use in plant improvement. Theor. Appl. Genet. 110:167-174.

10. Little, T. M., and Hills, F. J. 1978. Agriculture Experimentation. John Wiley \& Sons, New York.

11. Melchers, L. E. 1925. Diseases of cereal and forage crops in the United States in 1924. Plant Dis. Rep. Suppl. 40:186.

12. Mengistu, A., Kurtzweil, N. C., and Grau, C.R. 2002. First report of frogeye leaf spot (Cercospora sojina) in Wisconsin. Plant Dis. 86:1272.

13. Mian, M. A. R., Boerma, H. R., Phillips, D. V., Kenty, M. M., Shannon, G., Shipe, E. R. Soffes Blount, A. R., and Weaver, D. B. 1998. Performance of frogeye leaf spot resistant and susceptible near isolines of soybean. Plant Dis. 82:1017-1021.

14. Mian, M. A. R., Kang, S. T., Beil, S. E., and Hammond R. B. 2008. Genetic linkage mapping of the soybean aphid resistance gene in PI 243540. Theor. Appl. Genet. 117:955-962.

15. Mian, M. A. R., Missaoui, A. M., Walker, D. R., Phillips, D. V. and Boerma, H. R. 2008.
Frogeye leaf spot of soybean: a review and proposed race designations for isolates of $C$. sojina Hara. Crop Sci. 48:14-24.

16. Mian, M. A. R., Wang, T., Phillips, D. V., Alvernaz, J., and Boerma, H. R. 1999. Molecular mapping of the $R \operatorname{cs} 3$ gene for resistance to frogeye leaf spot of soybean. Crop Sci. 39:1687-1691.

17. Missaoui, A. M., Ha B. K., Phillips, D. V., and Boerma, H. R. 2007. Single nucleotide polymorphism detection of the Rcs 3 gene for resistance to frogeye leaf spot in soybean. Crop Sci. 47:1681-1690.

18. Missaoui, A. M., Phillips, D. V., and Boerma H. R. 2007. DNA marker analysis of 'Davis' soybean and its descendents for the Rcs 3 gene conferring resistance to Cercospora sojina. Crop Sci. 47:1263-1270.

19. Oetting, W. S., Lee, H. K., Flanders, D. J., Wiesner, G. L., Sellers, T. A., and King, R. A. 1995. Linkage analysis with multiplexed short tandem repeat polymorphisms using infrared fluorescence and M13 tailed primers. Genomics 30:450-458.

20. Pace, P. F., Weaver, D. B., and Ploper, L.,D. 1993. Additional genes for resistance to frogeye leaf spot race 5 in soybean. Crop Sci. 33:1144-1145.

21. Phillips, D. V. 1999. Frogeye leaf spot. Pages 20-21 in: Compendium of Soybean Diseases, Fourth Edition. G. L. Hartman, Sinclair, J. B., and Rupe J. C., eds. American Phytopathological Society Press, St. Paul, MN.

22. Phillips, D. V., and Boerma, H. R. 1982. Two genes for resistance to race 5 of Cercospora sojina in soybeans. Phytopathology 72:764-766.

23. Saghai Maroof, M. A., Soliman, K. M., Jorgensen, R. A., and Allard, R. W. 1984. Ribosomal DNA spacer-length polymorphisms in barley: Mendelian inheritance, chromosomal location, and population dynamics. Proc. Natl. Acad. Sci. USA 81:8014-8018.

24. Shannon, J. G., Lee, J. D., Wrather, J. A., Sleper, D. A., Mian, M. A. R., Bond, J. R., and Robbins, R. T. Registration of 'S99-2281' soybean germplasm line with resistance to frogeye leaf spot and three nematode species. J. Plant Registrations 3:94-98.

25. Sherwin, H. S., and Kreitlow, K. W. 1952. Discoloration of soybean seeds by the frogeye fungus, Cercospora sojina. Phytopathology 42:560-572.

26. Sinclair, J. B., ed. 1982. Introduction. Pages 1-2 in: Compendium of Soybean Diseases, Second Edition. J. B. Sinclair, ed. American Phytopathological Society Press, St. Paul, $\mathrm{MN}$

27. Tuite, J. 1969. Plant Pathological Methods. Burgess Publishing Co., Minneapolis, MN.

28. Wrather, J. A., and Koenning, S. R. 2006 Estimates of disease effects on soybean yields in the United States 2003-2005. J. Nematol. 38:173-180.

29. Yang, X. B., Uphoff, M. D., and Sanogo, S. 2001. Outbreaks of soybean frogeye leaf spot in Iowa. Plant Dis. 85:443.

30. Yorinori, J. T. 1992. Management of foliar fungal diseases in Brazil. Pages 185-193 in: Pest Management in Soybean. L. G. Copping, M. B. Green, and R. T. Rees, eds. Elsevier Applied Science, London. 